\title{
Emerging Trends in the Use of Therapeutic Hypothermia as a Method for Neuroprotection in Brain Damage (heview)
}

Dol: $10.17691 / \mathrm{stm} 2020.12 .5 .11$

Received December 18, 2019

E.Sh. Usmanov, Researcher, Laboratory of Clinical Neurophysiology;

M.A. Chubarova, Junior Researcher, Laboratory of Clinical Neurophysiology;

Sh.Kh. Saidov, MD, PhD, Senior Researcher, Laboratory of Clinical Neurophysiology

Federal Clinical Research Centre for Intensive Care Medicine and Rehabilitology, 777 Lytkino Village, Solnechnogorsk District, Moscow Region, 141534, Russia

The review analyzes current clinical studies on the use of therapeutic hypothermia as a neuroprotective method for treatment of brain damage. This method yields good outcomes in patients with acute brain injuries and chronic critical conditions. There has been shown the interest of researchers in studying the preventive potential of therapeutic hypothermia in secondary neuronal damage. There has been described participation of new molecules producing positive effect on tissues and cells of the central nervous system - proteins and hormones of cold stress - in the mechanisms of neuroprotection in the brain. The prospects of using targeted temperature management in treatment of brain damage are considered.

Key words: therapeutic hypothermia; neuroprotection; chaperones; cold shock hormones; cold shock proteins; controlled target temperature.

How to cite: Usmanov E.Sh., Chubarova M.A., Saidov Sh.Kh. Emerging trends in the use of therapeutic hypothermia as a method for neuroprotection in brain damage (review). Sovremennye tehnologii v medicine 2020; 12(5): 94, https://doi.org/10.17691/stm2020.12.5.11

\section{Introduction}

Medicine has been accumulating practical experience in the use of cooling agents for treatment and prevention of diseases during thousands of years. Hippocrates used snow and ice to stop bleeding in his patients [1]. In medieval times, hypothermia was used in the form of ice cubes to stop bleeding, in cases of cardiac arrest [2] and in comatose patients [3]. In the XIX century, Phelps used local head cooling in traumatic brain injuries [4, 5]. Whole-body exposure to cold was first used by neurosurgeon T. Fay in 1938 to treat head injuries. In the middle of the XX century, therapeutic hypothermia was forgotten due to increase in complications (bleeding, sepsis, heart rhythm disturbances) in the presence of general hypothermia when the patient's body was exposed to deeper and longer cooling.
However, hypothermia has begun to develop again in the past three decades. This is a highly effective neuroprotective method used in various fields of modern medical practice.

The discovery of neuroprotection development mechanisms in hypothermia has attracted great interest [6]. The authors [6] showed the role of this method in management of many neurological diseases such as acute cerebrovascular accident (ACVA), traumatic brain injury, spinal cord injury, hepatic encephalopathy, and neonatal encephalopathy.

Hypothermia at a temperature of $33.5^{\circ} \mathrm{C}$ is the standard treatment for newborns with hypoxic/ischemic encephalopathy: it is applied in this category of patients for $72 \mathrm{~h}[7]$.

Nielsen et al. [8] were the first to introduce the concept of controlled target temperature, which comprises a wider

Corresponding author: Eradj Sh. Usmanov, e-mail: eradzhik@gmail.com 
temperature range $\left(33-36^{\circ} \mathrm{C}\right)$ compared to therapeutic hypothermia and exerts a better effect on brain lesions. Moreover, the use of a target temperature has become increasingly widespread in cardiac surgery in patients with cardiac arrest to prevent anoxic brain damage [9]. Controlled target temperature in the range of $32-36^{\circ} \mathrm{C}$ for 24-48 $\mathrm{h}$ is one of the standard treatment algorithms in comatose patients after out-of-hospital cardiac arrest [10]. Preventive moderate and profound hypothermia also serves as standard management in cases of surgical interventions with possible cerebrovascular accidents such as cerebral aneurysms or in operations aimed to restore the aortic arch [11, 12]. In studies carried out at the Federal Clinical Research Centre for Intensive Care Medicine and Rehabilitology, great importance is attached to investigation of hypothermia in patients with chronic critical conditions. There have been observed clear positive effects exerted by this method on the level of consciousness in patients [13].

In clinical studies, Phadtare et al. [14] were the first to discover new molecules released through local and general body cooling - cold shock hormones (CSH) and cold shock proteins (CSP). They play an important role in the formation of progenitor cells for the nervous tissue of the brain, they are also necessary for repair and regeneration of damaged brain cells. The concept of "hypothermia in a syringe" has become a new trend in the development of therapeutic hypothermia [15]. It is based on neuroprotective cooling of individual organs and body systems while maintaining normal body temperature by intravenous administration of specific molecules inducing stress response to hypothermia and development of neuroprotection. This approach might have a wide range of applications: treatment of neurodegenerative diseases as well as acute and chronic critical conditions.

\section{Mechanisms of hypothermia-induced neuroprotection}

Therapeutic hypothermia is a promising method of neuroprotection against nerve cell damage. Its neuroprotective role has been best shown in experiments on dogs [16], rats [17], in patients with cardiac arrest [18], hypoxic/ischemic encephalopathies [19], traumatic brain injury [20], and some other diseases (Figure 1).

Despite the fact that hypothermic neuroprotection is still under research, its main mechanisms are likely to be a decrease in the level of nerve cell metabolism and free radical formation, reduced inflammatory changes, inhibition of excitotoxicity and apoptosis.

Various molecules may act as neuroprotectors. One of them is nestin, a neuroepithelial stem cell protein that belongs to cytoskeletal intermediate filaments. It was first described in the neural stem cells of the developing and developed brain. Nestin expression was found in stem cells of various tissues [21]. Notably, nestinpositive cells showing the ability to form neurospheres

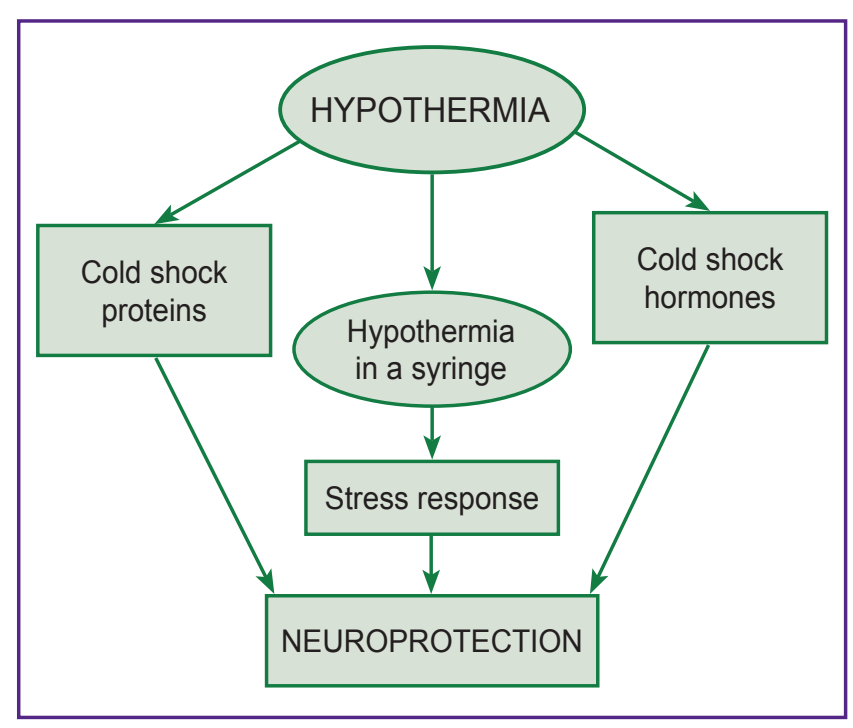

Figure 1. Neuroprotective mechanism in hypothermia

ex vivo and generate differentiated cells of the nervous and astrocytic lines are found in the brain [22].

$\beta$-tubulin III is another neuroprotective molecule, a microtubule element belonging to the family of tubulin proteins, one of the two main tubulins ( $\alpha$ - and $\beta$-tubulins) required for heterodimerization and assembly of microtubules. This type of protein is found almost exclusively in nerve and testicular tissue. When expressed in neural tissue, $\beta$-tubulin III is involved in neurogenesis, axon guidance (the process of axon growth towards its target), and cell maintenance [23].

Cerebral ischemia causes neuronal damage (for example, after cardiac arrest or ACVA) and contributes to secondary damage after brain injury (especially in combination with hypoxia and/or hypotension) [24-26]. The amount of adenosine triphosphate (ATP) required by neurons to survive is proportional to the metabolic rate of the brain. During ischemia, the death of cells occurs due to the imbalance between the supply of cells with ATP (loss of oxidative phosphorylation in hypoxia) and their need for it (high oxygen consumption by brain tissues). In hypothermia, a decrease in temperature by each degree Celsius (from 37 to $27^{\circ} \mathrm{C}$ ) is known to promote a decrease in oxygen consumption by brain tissues by $6-7 \%[27,28]$. Therefore, hypothermia is able to limit or prevent the development of ischemia during the episodes of impaired or completely absent blood flow in the brain due to decreased ATP consumption and the need to provide vitally important tissues with oxygen [29].

Oxidative stress contributes to tissue damage after traumatic brain injury due to increased production of toxic oxidation products (reactive oxygen species (ROS) and reactive nitrogen species (RNS)) and a decrease in the level of intracellular oxygen neutralization mechanisms. There are a large number of conditions for generation of ROS and RNS, including disturbances in the mitochondrial respiratory chain, activation of 
stimulating enzymes (xanthine oxidase, NADPH oxidase), and circulation of redox agents (free iron). The cumulative impact of these phenomena is exhibited as direct damage to proteins, lipids, and RNA/DNA [30]. Therapeutic hypothermia inhibits oxidative damage to the brain by reducing these processes [31-33] and enhancing antioxidant protection, which has been shown in clinical studies and in patients with various CNS injuries [34, 35].

Brain damage caused by excessive neuronal depolarization leads to intracellular $\mathrm{Ca}^{2+}$ overload and continuous production of glutamate (excitotoxicity) $[36,37]$. Moreover, extracellular glutamate level also increases due to pathological changes in its astrocytic transporters [38]. The final effect of these events is rapid activation of extrasynaptic N-methyl-Daspartate receptors, promoting intracellular apoptotic signaling cascade and subsequent neuron death [39]. Hypothermia potently inhibits neuronal death caused by direct incorporation of glutamate into the brain parenchyma [40]. In addition, brain cooling prevents posttraumatic surges of extracellular glutamate during ischemia [41, 42], brain concussions [31], subarachnoid hemorrhages [43, 44], and bacterial meningitis [45].

Release of intracellular DNA and dying cell debris into the extracellular space and secretion of additional damage-associated molecular patterns trigger production of pro-inflammatory cytokines (increased levels of TNF, INF- $y$, and IL-6) [46, 47]. Moreover, neutrophils rapidly accumulate in the early stages after trauma and in the reperfusion phase after ischemia [48, 49]. The production of cytokines stimulates the proinflammatory (M1/M1-like) phenotype in macrophages and microglia [50,51]. These events are a powerful mechanism of damage to CNS tissue. In the chronic phase, under ideal conditions, macrophages and microglia switch to the anti-inflammatory (M2/M2like) phenotype, promoting recovery and lesion size reduction. However, recent studies have shown that the M2/M2-like phases reach their peak in the subacute and early chronic stages after brain injury, followed by a prolonged and negative phase of shifting towards the M1/M1-like phenotypes [52]. Hypothermia reduces neuronal inflammation by blocking the above triggers and shifting the monocytes towards the antiinflammatory M2 phenotype [53, 54].

The blood-brain barrier (BBB) maintains the chemical composition of the brain interstitial fluid and is an essential structure required for the normal functioning of the central nervous system [55]. Increased BBB permeability due to mechanical damage after traumatic brain injury or in various pathological processes promotes penetration of pathogens and toxic micro/macromolecules into the underlying cerebral parenchyma $[56,57]$. At the same time, migration of erythrocytes into the perivascular space with subsequent hemolysis leads to an increase in extracellular hemoglobin and free iron, aggravating the damage due to ROS [58]. Hypothermia reduces damage to the BBB in trauma [59,60], ACVA [61, 62], bacterial meningitis [63], and intracerebral hemorrhage [64]. In hypothermia, protective mechanisms include inhibition of matrix metalloproteinases [65], preservation of proteins, tight junctions [66], reducing the level of intracellular ICAM-1 (cell adhesion molecule) on the vascular endothelial surface, they prevent diapedesis $[59,67]$.

The above injuries stimulate a variety of downstream signaling pathways that trigger different types of cell death mechanisms and lead to secondary brain damage. Each cell death mechanism has its own unique "molecular signature" including numerous effector molecules and signaling cascades. When using mild to moderate hypothermia, positive effects show as inhibition of the level of damaging enzymes or target molecules that trigger apoptosis [68, 69], necrosis [70], autophagy $[64,71]$, necroptosis [72], or pyroptosis [73, 74].

\section{Heat shock proteins}

Various proteins released under the influence of stress on the body trigger cellular recovery mechanisms. Heat shock proteins (Hsp) are a class of reparative molecules. Therapeutic hypothermia is a powerful stimulus for Hsp production in brain cells. Exposure to low temperatures forms resistance of neurons to stress and stimulates progenitor cells, which in turn replenish and replace dead nerve cells.

Correct protein assembly process consisting of translation, transcription, and termination of the protein chain occurs in the presence of molecular chaperones, proteins involved in recognition and selective binding of foreign protein molecules, forming stable complexes [75]. They play an important role in protein assembly by preventing incorrect folding and aggregation of assembly components [76]. Hsp are molecular chaperones assisting the correct assembly of newly synthesized proteins as well as those susceptible to denaturation due to stress. In addition to their chaperone role, Hsp exhibit cytoprotective functions [77] and inhibit the apoptotic cascade [78].

Heat shock proteins are classified into different families based on molecular weight measured in kilodaltons (kDa): Hsp100, Hsp90, Hsp70, Hsp60, Hsp40, and smaller. Almost all families have representatives that play the role of constitutive proteins (produced irrespective of stress effects on the body cells) and inducible proteins (their synthesis is weak under normal conditions, but it increases sharply under stress effects on the cell). Hsp70 is the most studied chaperone promoting correct assembly and transfer of various protein molecules [79].

The main transcription factor responsible for activation of heat shock proteins is heat shock factor 1 (HSF1) [80] (Figure 2). Under physiological conditions, it is associated with Hsp90, which inhibits its transcriptional 


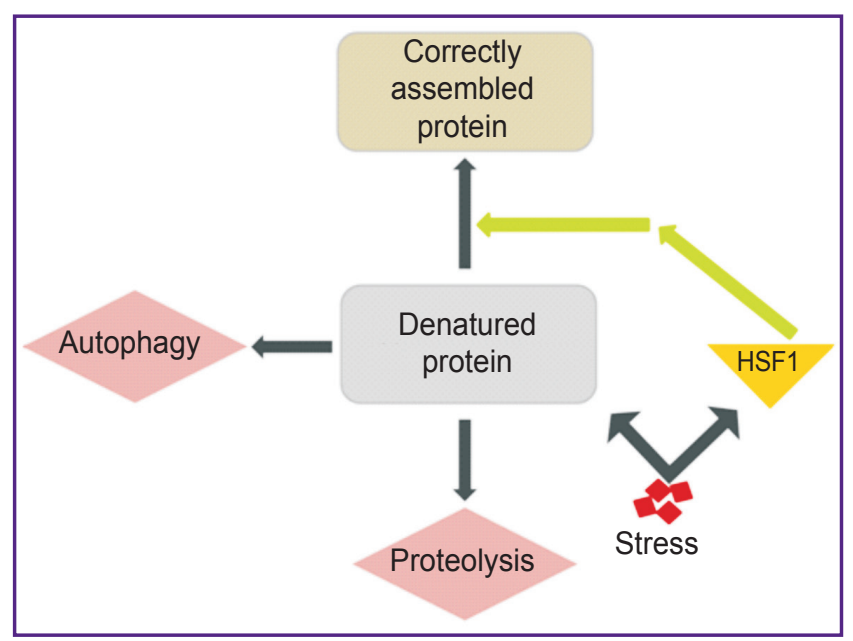

Figure 2. Induction of HSF1 and chaperones in response to stress

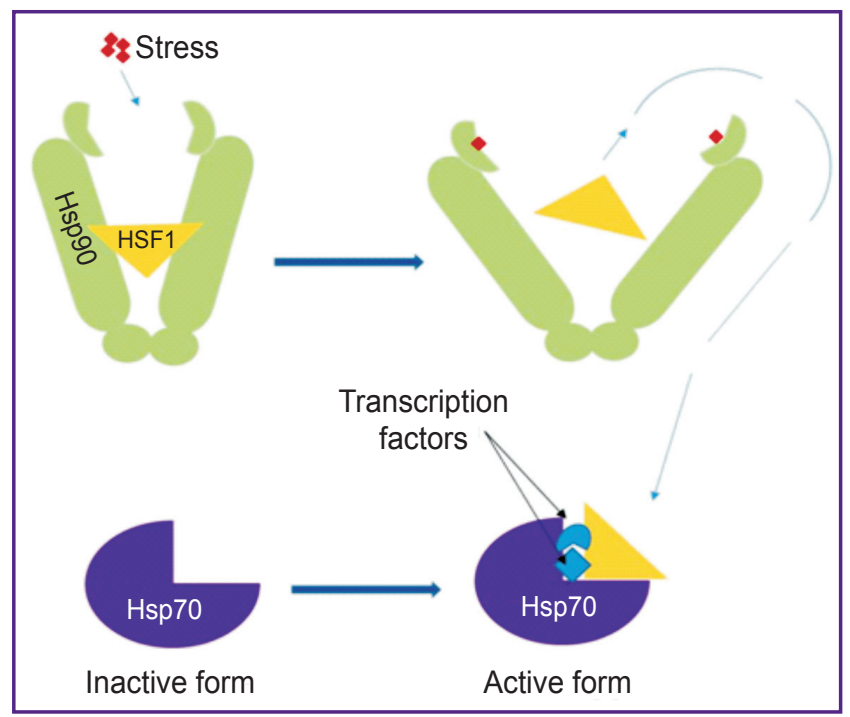

Figure 3. Release of HSF1 from the Hsp90 complex under the influence of stress and resulting activation of inducible Hsp70

activity, forming an inactive complex with it. Under stress conditions, released stress molecules bind to Hsp90 releasing HSF1, which in turn forms a bond with members of other heat shock protein families, inducing their expression [81]. Released from the complex, HSF1 migrates into the nucleus and binds Hsp gene promoters, which leads to increased regulation of these genes [80] (Figure 3).

Heat shock proteins are induced in the CNS by various pathological processes including ACVA, neurodegenerative diseases, epilepsy, and trauma [82]. Their expression is detected in various types of cells, including neurons, glia, and endothelial cells. They are also found as extracellular proteins formed by physiological secretory mechanisms and during cell necrosis. In the extracellular environment, these proteins increase resistance to stress by binding to stresssensitive cells, including neurons [83].

When damaged, the brain becomes very vulnerable to even small temperature fluctuations [84]. Changes in the cellular environment of the brain during temperature stress involve formation of free radicals, changes in the mechanisms of nerve impulse transmission or a decrease in neuronal protein synthesis, and changes in gene expression.

Fluctuations in body temperature can lead to the death of brain cells and tissues (neurodegenerative changes) [85]. The necessary condition for repairing damaged brain cells is the presence of stem cells (progenitor cells). The potential of neural progenitor cells as a source of CNS tissue repair and regeneration was proved in work [86].

\section{Cold shock proteins and hormones}

Along with its classic uses, hypothermia triggers mechanisms and events that function owing to production of cold shock hormones (CSH) and cold shock proteins (CSP).

Here, we consider the most studied cold shock hormones. Most fibroblast growth factors (FGFs) are paracrine hormones [87]. The proteoglycan-binding domain of heparin sulfate limits their activity up to complete shutdown [88]. In contrast, FGF21 is a member of the endocrine subtype, which includes FGF19, FGF21, and FGF23. Endocrine growth factors have lost their heparin-binding capacity during evolution, which allows them to circulate freely after being produced [89]. As a result, they use klotho transmembrane proteins as co-receptors ( $\alpha$-klotho and/or $\beta$-klotho) that play the role of molecular binders to facilitate and stabilize interaction between extracellular ligands and tissue receptors [90, 91]. The $\beta$-klotho protein is an obligatory co-receptor for FGF21 required for ligand binding and activation of the FGFR1c receptor in vivo [92, 93]. It was also shown that in vitro $\beta$-klotho protein increases affinity of FGF21 to bind to various isoforms of FGF receptors, but the magnitude of their activation depends on the type of receptor on target organs (FGFR1C > FGFR2C > FGFR3c) [92]. Moreover, $\beta$-klotho protein expression is limited to the following organs: liver, pancreas, adipose tissue, and some populations of hypothalamic and hindbrain neurons [94, 95].

Circulation of FGF21 increases in humans and rodents under cold stress. In humans, this phenomenon was proved in study [96], when patients wearing only hospital suits were left for $12 \mathrm{~h}$ in a ward with the surrounding temperature reduced to $19^{\circ} \mathrm{C}$, after which the FGF21 level was measured in these patients and those in the wards with thermoneutral surrounding temperature $\left(24^{\circ} \mathrm{C}\right)$.

Studies [97] show that an increase in FGF21 levels can improve brain function after acute pathologies and in chronic neurodegenerative conditions. The effects 
of FGF21 are believed to have direct and indirect mechanisms of action; it has also been revealed that FGF21 penetrates the BBB.

The direct effect of this factor was shown in work [97], where 5 nmol FGF21 was injected into samples for 6 days in vitro, which resulted in a decrease in damage to cells with FGF21 receptors due to glutamate. In addition, there was observed an increase in phosphorylation of neural AKT (AKT-1 kinase), ERK (extracellular signal-regulated kinases), and GSK-3 $\beta$ (glycogen synthase kinase), which lead to increased cell survival and neuroprotection. The authors of [98] argue that peripherally derived FGF21 promotes remyelination in the brain and spinal cord due to lysophosphatidylcholine. In study [99], it was found in vitro that FGF21 reduces damage to neurons induced by $A \beta 1-42$ (a structural variant of $\beta$-amyloid) in patients with Alzheimer's disease. It was also noted [100] that administration of FGF21 to normothermal subjects improved the BBB integrity, reduced cerebral edema and tissue damage, along with improvement in recovery from neurologic impairment. In [101], it was demonstrated that 14 days of therapy with $1.5 \mathrm{mg} / \mathrm{kg}$ of recombinant FGF21 (started $6 \mathrm{~h}$ after injury) reduced metabolic dysfunction, neuronal inflammation, reduced the area of cerebral infarction, white matter damage, and improved neurological results after focal ACVA. Finally, it was shown in vivo [102] that increased stress in the endoplasmic reticulum of brain neurons leads to phosphorylation of eukaryotic initiation factor 2 alpha (elF2 $\alpha$ ), which in turn stimulates activation of transcription factor 4 (ATF4) and leads to an increase in neuronal expression of FGF21. The indirect mechanism of FGF21 action is stimulation of ketogenesis in the liver. Ketone bodies (acetone, acetoacetate, and $\beta$-hydroxybutyrate) are efficiently delivered to the brain where they serve as an alternative source of energy for oxidative metabolism [103].

Another mechanism of indirect action is the impact of FGF21 on the blood glucose level: this factor leads to its normalization [104]. However, unlike insulin, FGF21 normalizes blood glucose levels without inducing hypoglycemia [105]. Thus, stimulation or administration of FGF21 may be the best strategy for glycemic control in critically ill patients.

Irisin is a glycosylated protein fragment secreted by muscle tissue in response to training stress and muscle contraction (tremor) during cooling. The more contractions a muscle makes, the higher blood irisin level will be reached [106, 107].

Irisin is a neuroprotective hormone. It was found that intravenous introduction of $200 \mathrm{mg} / \mathrm{kg}$ of this substance 30 min after occlusion of the middle cerebral artery in ACVA model reduced the volume of cerebral infarction after 3 days [108]. It was revealed in another study [109] that irisin administration at a dose of $7.5 \mathrm{mg} / \mathrm{kg}$ directly into the ventricular system of the brain reduced the severity of neurological deficit, reduced infarction area, and edema of brain tissue. It was also observed that irisin influenced BDNF promoting its production and enhancing immunoreactivity. These phenomena lead to an increase in the neuroprotective properties of the brain and reduction of apoptosis. The impact of this hormone still requires further investigation, but it has already proved to be very promising as a factor for recovery and protection of neuroglia and astrocytes, which is worth investigating both in patients with acute and chronic critical conditions and in those with neurodegenerative diseases of the central nervous system.

Meteorin-like hormone was first identified as a factor of fat mobilization and PGC-1a4 expression (a hypertrophy regulator) in muscles. This hormone was found to have a stimulating effect on the anti-inflammatory function of macrophages due to the eosinophil-dependent expression of IL-4 [110]. CNS immune cells, including microglia and infiltrating macrophages, alter the extracellular microenvironment after brain damage [111]. Microglia and M1-type macrophages produce pro-inflammatory cytokines, while M2-type cells promote release of anti-inflammatory factors. Work [61] demonstrates that therapeutic hypothermia at $33^{\circ} \mathrm{C}$ for four hours increased the ratio of M2/M1 microglia and lymphocytes in the damaged cortex after concussion. Moreover, the authors of this study have shown that hypothermia increases expression of pro-inflammatory cytokines, including IL-10 and TGF- $\beta$.

Meteorin circulating in the blood activates antiinflammatory pathways of macrophages, leading to their conversion into the M2 type.

Cold shock proteins are produced during cold stress and stimulate cold adaptation in cells. After these proteins appear, they remain inside the cell and their level increases progressively with temperature decreasing below thermoneutral values. The therapeutic effect is achieved due to signaling pathway stimulation and leads to neuroprotection. We consider three clinically significant cold shock proteins: RNA-binding motif 3, cold-inducible RNA-binding protein, and Reticulon-3.

RNA-binding motif 3 (RBM3) was first described in study [112] demonstrating that cooling the body to $32^{\circ} \mathrm{C}$ for $24 \mathrm{~h}$ leads to an increase in RBM3 levels in mammals. Recent studies [113] have confirmed that hypothermia increases RBM3 levels in major neurons of the brain. An increase in RBM3 of messenger RNA (mRNA) was also observed in brain culture cells after incubation at $32^{\circ} \mathrm{C}$ for $72 \mathrm{~h}$.

RBM3 is a potent neuroprotective agent. In patients with Huntington's disease, there was observed a decrease in mRNA RBM3 in cells expressing toxic polyglutamine fragment $\mathrm{HD}-74 \mathrm{Q}$. It has been shown [114] that the exogenous administration of RBM3 leads to inhibition of HD-74Q and reduces mortality of cells affected by this fragment.

Increased RBM3 expression was also reported to reduce nitric oxide-induced cell death in neurons [115]. Delayed neuronal death is often observed in acute brain injuries [116, 117]. In vitro and in vivo experiments 


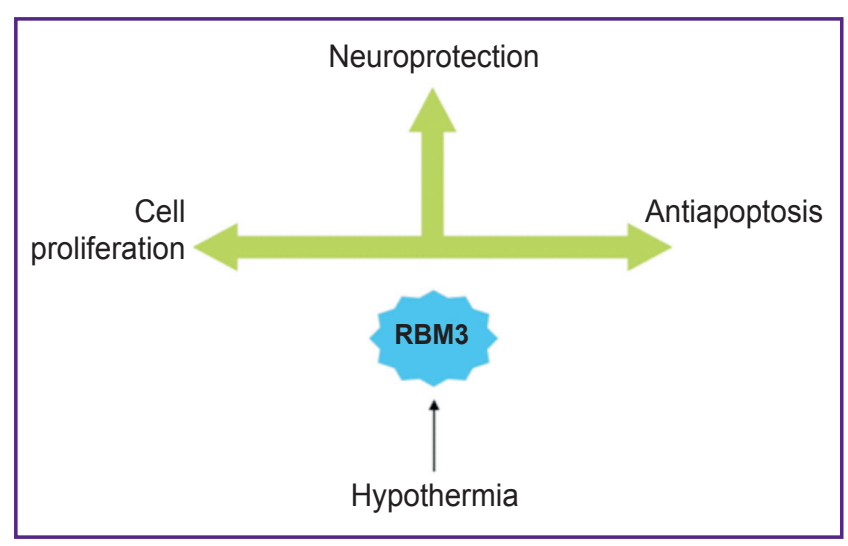

Figure 4. The main functions of the RBM3 protein

showed that production of RBM3 increased mRNA function, which in turn ensured survival of injured neurons [118, 119] (Figure 4).

Cold-inducible RNA-binding protein (CIRBP) as a representative of cold shock proteins was first discovered in the experiments of Nishiyama [120].

Modern in vitro and in vivo studies have found the level of CIRBP to increase in the main neurons of the brain under the influence of hypothermia. Studies by $\mathrm{Li}$ et al. [121] show that a decrease in cerebral cortex temperature to $32^{\circ} \mathrm{C}$ for $2 \mathrm{~h}$ increases CIRBP levels. Later Zhang et al. [122] demonstrated that exposure of cortical neurons to $32^{\circ} \mathrm{C}$ for $12 \mathrm{~h}$ also increased CIRBP. Similar results were obtained in the setting of complete body cooling, when an increase in CIRBP in vivo was recorded. Induced complete cooling of the body $\left(31^{\circ} \mathrm{C}\right)$ in adult rats during $48 \mathrm{~h}$ promoted increased production of CIRBP in the hypothalamus [123]. Another study reports increased phosphorylation (activation) of the protective kinases $\mathrm{pERK}$ and $\mathrm{pAKT}$ due to CIRBP production after hypothermia [124]. Moreover, hypothermia increases release of protective proteins, including CIRBP, Bcl-2, and AKT, while decreasing apoptosis proteins such as Bax, Bad, Bak, caspase-3, caspase-9, and Apaf1 [125].

Neuroprotective properties of CIRBP have been revealed in cases of post-traumatic brain injury [123]. The level of this protein increased in the hypothalamus of rats after brain injury and remained elevated for $48 \mathrm{~h}$ after cooling to $31^{\circ} \mathrm{C}$ during $48 \mathrm{~h}$. The same study has reported on decreased levels of apoptosis in damaged cells of the cerebral cortex, hippocampus, and hypothalamus.

Study [126] notes that hypoxia decreases proliferation of cells lacking cold-inducible RNA-binding protein. CIRBP blocks the death of these neurons. Hypothermia protects them by preventing apoptosis and reducing the function of targets for apoptotic proteins, including HIF1a.

The latest representative of cold shock proteins is Reticulon-3 (RTN3A1) first described by Moreira et al. in 1999 [127]. The authors of [128] showed that RTN3A1 is a cold shock protein as it is produced in neurons while cooling. This protein is a modulator of pathogenesis in Alzheimer's disease. The precursor of $\beta$-amyloid BACE1 stimulates processing of the amyloid precursor protein (APP) into $\beta$-amyloid that forms blue plaques in the brain [129]. Inhibition of BACE1 is one of the possible treatment options for Alzheimer's disease and RTN3A1 inhibits BACE1 via two mechanisms. The first is inhibition of axonal transport of BACE1 protein to synapses, which impairs its interaction with APP reducing formation of blue plaques; the second is a decrease in the number of neurotoxic fragments $(A \beta 1-40$ and $A \beta 1-42)$ in the cerebral cortex [130].

\section{Conclusion}

Therapeutic hypothermia is a powerful neuroprotective method affecting the brain through a variety of mechanisms. Promoting production of heat shock proteins, this method builds neuronal resistance to stress and in turn stimulates progenitor cells regenerating and replacing dead nerve cells. Therapeutic hypothermia generates cell differentiation of the nervous and astrocytic lines by stimulating production of nestin. Application of this method offers the possibility to limit or prevent development of ischemia in the absence of blood flow to the brain due to decreased ATP consumption and the need to provide vitally important tissues with oxygen. Produced during hypothermia, cold shock hormones and proteins have anti-inflammatory, neuroprotective, and stimulating effects on brain cells, which makes them one of the most important mechanisms triggered by therapeutic hypothermia.

The studies of recent decades offer us the opportunity to make sure of the immensity of proven effects obtained through therapeutic hypothermia, but at the same time, there is a huge field for discovering new possibilities of this method, manifested at the molecular level. It is still necessary to study, develop, and apply therapeutic hypothermia for treatment of patients in acute and chronic critical conditions.

Authors' contributions. E.Sh. Usmanov, analysis of literary sources, developing the concept and design of the article, preparing the manuscript; M.A. Chubarova, developing the article design and text editing; Sh.Kh. Saidov, developing the idea and concept of the article, selection of literary sources.

Study funding and conflict of interest. This study was not supported by any financial sources and the authors have no conflict of interest to disclose.

\section{References}

1. Jones W.H.S., Withington E.T. (translators). Hippocrates. De Vetere Medicina. Loeb Classical Library; 460-375 BC.

2. Dzięcioł M., Kacprzak M., Goleniewska B., Zielińska M. Osborn wave in patients with ST-elevation myocardial infarction undergoing mild hypothermia after cardiac arrest. 
Acta Cardiol 2014; 69(5): 532-540, https://doi.org/10.2143/ AC.69.5.3044880.

3. Dell'Anna A.M., Taccone F.S., Halenarova K., Citerio G. Sedation after cardiac arrest and during therapeutic hypothermia. Minerva Anestesiol 2014; 80(8): 954-962.

4. Phelps C. Principles of treatment. In: Traumatic injuries of the brain and its membranes. New York: D. Appleton and Co.; 1897.

5. Karnatovskaia L.V., Wartenberg K.E., Freeman W.D. Therapeutic hypothermia for neuroprotection: history, mechanisms, risks and clinical applications. Neurohospitalist 2014; 4(3): 153-163, https://doi.org/10.1177/ 1941874413519802.

6. Jackson T.C., Kochanek P.M. A new vision for therapeutic hypothermia in the era of targeted temperature management: a speculative synthesis. Ther Hypothermia Temp Manag 2019; 9(1): 13-47, https://doi.org/10.1089/ther.2019.0001.

7. Martinello K., Hart A.R., Yap S., Mitra S., Robertson N.J. Management and investigation of neonatal encephalopathy: 2017 update. Arch Dis Child Fetal Neonatal Ed 2017; 102(4): F346-F358, https://doi.org/10.1136/archdischild-2015-309639.

8. Nielsen N., Wetterslev J., Cronberg T., Erlinge D., Gasche Y., Hassager C., Horn J., Hovdenes J., Kjaergaard J., Kuiper M., Pellis T., Stammet P., Wanscher M., Wise M.P., Åneman A., Al-Subaie N., Boesgaard S., Bro-Jeppesen J., Brunetti I., Bugge J.F., Hingston C.D., Juffermans N.P., Koopmans M., Køber L., Langørgen J., Lilja G., Møller J.E., Rundgren M., Rylander C., Smid O., Werer C., Winkel P., Friberg H.; TTM Trial Investigators. Targeted temperature management at $33^{\circ} \mathrm{C}$ versus $36^{\circ} \mathrm{C}$ after cardiac arrest. $N$ Engl J Med 2013; 369(23): 2197-2206, https://doi.org/10.1056/ NEJMoa1310519.

9. Kuroda Y., Kawakita K. Targeted temperature management for postcardiac arrest syndrome. J Neurocrit Care 2020; 13(1): 1-18, https://doi.org/10.18700/jnc.200001.

10. Callaway C.W., Donnino M.W., Fink E.L., Geocadin R.G., Golan E., Kern K.B., Leary M., Meurer W.J., Peberdy M.A., Thompson T.M., Zimmerman J.L. Part 8: post-cardiac arrest care: American Heart Association guidelines update for cardiopulmonary resuscitation and emergency cardiovascular care. Circulation 2015: 132(18 Suppl 2): S465-S482, https://doi. org/10.1161/CIR.0000000000000262.

11. Hanel R.A., Spetzler R.F. Surgical treatment of complex intracranial aneurysms. Neurosurgery 2008; 62(6 Suppl 3): 12891297, https://doi.org/10.1227/01.neu.0000333794.13844.d9.

12. Tian D.H., Wan B., Bannon P.G., Misfeld M., LeMaire S.A., Kazui T., Kouchoukos N.T., Elefteriades J.A., Bavaria J., Coselli J.S., Greipp R.B., Mohr F.W., Oo A., Svensson L.G., Hughes G.C., Yan T.D. A meta-analysis of deep hypothermic circulatory arrest versus moderate hypothermic circulatory arrest with selective antegrade cerebral perfusion. Ann Cardiothorac Surg 2013; 2(2): 148-158, https://doi. org/10.3978/j.issn.2225-319X.2013.03.13.

13. Shevelev O.A., Grechko A.V., Petrova M.V. Terapevticheskaya gipotermiya [Therapeutic hypothermia]. Moscow: RUDN; 2019.

14. Phadtare S., Alsina J., Inouye M. Cold-shock response and cold-shock proteins. Curr Opin Microbiol 1999; 2(2): 175180, https://doi.org/10.1016/S1369-5274(99)80031-9.

15. Jinka T.R., Tøien O., Drew K.L. Season primes the brain in an arctic hibernator to facilitate entrance into torpor mediated by adenosine $A_{1}$ receptors. J Neurosci 2011; 31: 10752-10758, https://doi.org/10.1523/JNEUROSCI.1240-11.2011.
16. Leonov Y., Sterz F., Safar P., Radovsky A., Oku K., Tisherman S., Stezoski S.W. Mild cerebral hypothermia during and after cardiac arrest improves neurologic outcome in dogs. J Cereb Blood Flow Metab 1990; 10(1): 57-70, https://doi. org/10.1038/jcbfm.1990.8.

17. Ridenour T.R., Warner D.S., Todd M.M., McAllister A.C. Mild hypothermia reduces infarct size resulting from temporary but not permanent focal ischemia in rats. Stroke 1992; 23(5): 733-738, https://doi.org/10.1161/01.str.23.5.733.

18. Hakim S.M., Ammar M.A., Reyad M.S. Effect of therapeutic hypothermia on survival and neurological outcome in adults suffering cardiac arrest: a systematic review and metaanalysis. Minerva Anestesiol 2018; 84(6): 720-730, https://doi. org/10.23736/S0375-9393.18.12164-X

19. Yum S.K., Seo Y.M., Kwun Y., Moon C.J., Youn Y.A., Sung I.K. Therapeutic hypothermia in infants with hypoxicischemic encephalopathy and reversible persistent pulmonary hypertension: short-term hospital outcomes. Matern Fetal Neonatal Med 2018; 31(23): 3108-3114, https://doi.org/10.1080/ 14767058.2017.1365123.

20. Leng L. Hypothermia therapy after traumatic brain injury: a systematic review and meta-analysis. Turk Neurosurg 2017, https://doi.org/10.5137/1019-5149.JTN.19696-16.2.

21. Bernal A., Arranz L. Nestin-expressing progenitor cells: function, identity and therapeutic implications. Cell Mol Life Sci 2018; 75(12): 2177-2195, https://doi.org/10.1007/s00018-0182794-z.

22. Mignone J.L., Kukekov V., Chiang A.S., Steindler D., Enikolopov G. Neural stem and progenitor cells in nestin-GFP transgenic mice. Comp Neurol 2004; 469(3): 311-324, https:// doi.org/10.1002/cne.10964.

23. Tubulin beta 3 class III. URL: https://www.ncbi.nlm.nih. gov/gene/10381.

24. Kaufmann A.M., Firlik A.D., Fukui M.B., Wechsler L.R., Jungries C.A., Yonas $\mathrm{H}$. Ischemic core and penumbra in human stroke. Stroke 1999; 30(1): 93-99, https://doi.org/10.1161/01. str.30.1.93

25. Coles J.P., Fryer T.D., Smielewski P., Chatfield D.A., Steiner L.A. Incidence and mechanisms of cerebral ischemia in early clinical head injury. J Cereb Blood Flow Metab 2004; 24(2): 202-211, https://doi.org/10.1097/01.WCB.0000103022.98348.24.

26. Iordanova B., Li L., Clark R.S.B., Manole M.D. Alterations in cerebral blood flow after resuscitation from cardiac arrest. Front Pediatr 2017; 5: 174, https://doi.org/10.3389/ fped.2017.00174.

27. Edgar A., Bering J. Effect of body temperature change on cerebral oxygen consumption of the intact monkey. Am J Physiol 1961; 200: 417-419, https://doi.org/10.1152/ ajplegacy.1961.200.3.417

28. Steen P.A., Newberg L., Milde J.H., Michenfelder J.D. Hypothermia and barbiturates: individual and combined effects on canine cerebral oxygen consumption. Anesthesiology 1983; 58(6): 527-532.

29. Metz C., Holzschuh M., Bein T., Woertgen C., Frey A., Frey I., Taeger K., Brawanski A. Moderate hypothermia in patients with severe head injury: cerebral and extracerebral effects. J Neurosurg 1996; 85(4): 533-541, https://doi. org/10.3171/jns.1996.85.4.0533.

30. Kohen R., Nyska A. Oxidation of biological systems: oxidative stress phenomena, antioxidants, redox reactions, and methods for their quantification. Toxicol Pathol 2002; 30(6): 620-650, https://doi.org/10.1080/01926230290166724.

31. Lei B., Adachi N., Arai T. The effect of hypothermia 
on $\mathrm{H}_{2} \mathrm{O}_{2}$ production during ischemia and reperfusion: a microdialysis study in the gerbil hippocampus. Neurosci Lett 1997; 222(2): 91-94, https://doi.org/10.1016/s03043940(97)13349-3.

32. Globus M.Y., Alonso O., Dietrich W.D., Busto R., Ginsberg M.D. Glutamate release and free radical production following brain injury: effects of posttraumatic hypothermia. J Neurochem 1995; 65(4): 1704-1711, https://doi.org/10.1046/ j.1471-4159.1995.65041704.x.

33. Chatzipanteli K., Wada K., Busto R., Dietrich W.D. Effects of moderate hypothermia on constitutive and inducible nitric oxide synthase activities after traumatic brain injury in the rat. J Neurochem 1999; 72(5): 2047-2052, https://doi.org/10.1046/ j.1471-4159.1999.0722047.x.

34. Bayir H., Adelson P.D., Wisniewski S.R., Shore P., Lai Y., Brown D., Janesko-Feldman K.L., Kagan V.E., Kochanek P.M. Therapeutic hypothermia preserves antioxidant defenses after severe traumatic brain injury in infants and children. Crit Care Med 2009; 37(2): 689-695, https://doi.org/10.1097/ CCM.0b013e318194abf2.

35. Hackenhaar F.S., Medeiros T.M., Heemann F.M., Behling C.S., Putti J.S., Mahl C.D., Verona C., da Silva A.C.A., Guerra M.C., Gonçalves C.A.S., Oliveira V.M., Riveiro D.F.M., Vieira S.R.R., Benfato M.S. Therapeutic hypothermia reduces oxidative damage and alters antioxidant defenses after cardiac arrest. Oxid Med Cell Longev 2017; 2017: 8704352, https://doi. org/10.1155/2017/8704352.

36. Chamoun R., Suki D., Gopinath S.P., Goodman J.C., Robertson C. Role of extracellular glutamate measured by cerebral microdialysis in severe traumatic brain injury. J Neurosurg 2010; 113(3): 564-570, https://doi. org/10.3171/2009.12.JNS09689.

37. Schober A., Warenits A.M., Testori C., Weihs W., Hosmann A., Högler S., Sterz F., Janata A., Scherer T., Magnet I.A., Ettl F., Laggner A.N., Herkner H., Zeitlinger M. Microdialysis assessment of cerebral perfusion during cardiac arrest, extracorporeal life support and cardiopulmonary resuscitation in rats - a pilot trial. PloS One 2016; 11(5): e0155303, https://doi.org/10.1371/journal.pone.0155303.

38. Gouix E., Léveillé F., Nicole O., Melon C., Aissouni L., Buisson A. Reverse glial glutamate uptake triggers neuronal cell death through extrasynaptic NMDA receptor activation. Mol Cell Neurosci 2009; 40(4): 463-473, https://doi.org/10.1016/j. mcn.2009.01.002.

39. Hardingham G.E., Fukunaga Y., Bading H. Extrasynaptic NMDARs oppose synaptic NMDARs by triggering CREB shutoff and cell death pathways. Nat Neurosci 2002; 5(5): 405-414, https://doi.org/10.1038/nn835.

40. Suehiro E., Fujisawa H., Ito H., Ishikawa T., Maekawa T. Brain temperature modifies glutamate neurotoxicity in vivo. J Neurotrauma 1999; 16(4): 285-297, https://doi.org/10.1089/ neu.1999.16.285.

41. Mitani A., Kataoka K. Critical levels of extracellular glutamate mediating gerbil hippocampal delayed neuronal death during hypothermia: brain microdialysis study. Neuroscience 1991; 42(3): 661-670, https://doi.org/10.1016/0306-4522(91) 90035-m.

42. Campos F., Pérez-Mato M., Agulla J., Blanco M., Barral D., Almeida A., Brea D., Waeber C., Castillo J., RamosCabrer P. Glutamate excitoxicity is the key molecular mechanism which is influenced by body temperature during the acute phase of brain stroke. PloS One 2012; 7(8): e44191, https://doi. org/10.1371/journal.pone.0044191.
43. Shuaib A., Kanthan R., Goplen G., Griebel R., el-Azzouni H., Miyashita H., Liu L., Hogan T. In-vivo microdialysis study of extracellular glutamate response to temperature variance in subarachnoid hemorrhage. Acta Neurochir Supp/ 1996; 67: 53-58, https://doi.org/10.1007/9783-7091-6894-3_12.

44. Schubert G.A., Poli S., Mendelowitsch A., Schilling L., Thomé C. Hypothermia reduces early hypoperfusion and metabolic alterations during the acute phase of massive subarachnoid hemorrhage: a laser-Doppler-flowmetry and microdialysis study in rats. Neurotrauma 2008; 25(5): 539-548, https://doi.org/10.1089/neu.2007.0500.

45. Irazuzta J.E., Zingarelli B., Milam K., Kiefaber M., Kamdar T. Hypothermia attenuates inflammation in bacterial meningitis. Pediatr Res 1999; 45: 41a, https://doi. org/10.1203/00006450-199904020-00250.

46. Frugier T., Morganti-Kossmann M.C., O'Reilly D., McLean C.A. In situ detection of inflammatory mediators in post mortem human brain tissue after traumatic injury. Neurotrauma 2010; 27(3): 497-507, https://doi.org/10.1089/neu.2009.1120.

47. Ansari M.A. Temporal profile of $M 1$ and $M 2$ responses in the hippocampus following early $24 \mathrm{~h}$ of neurotrauma. J Neurol Sci 2015; 357(1-2): 41-49, https://doi.org/10.1016/j. jns.2015.06.062.

48. Garcia J.H., Liu K.F., Yoshida Y., Lian J., Chen S., del Zoppo G.J. Influx of leukocytes and platelets in an evolving brain infarct (Wistar rat). Am J Pathol 1994; 144(1): 188-199.

49. Price C.J., Menon D.K., Peters A.M., Ballinger J.R., Barber R.W. Cerebral neutrophil recruitment, histology, and outcome in acute ischemic stroke: an imaging-based study. Stroke 2004; 35(7): 1659-1664, https://doi.org/10.1161/01. STR.0000130592.71028.92.

50. Harting M.T., Jimenez F., Adams S.D., Mercer D.W., Cox C.S. Jr. Acute, regional inflammatory response after traumatic brain injury: implications for cellular therapy. Surgery 2008; 144(5): 803-813, https://doi.org/10.1016/j. surg.2008.05.017.

51. Boddaert J., Bielen K., Jongers B., Manocha E., Yperzeele L., Cras P., Pirici D., Kumar-Singh S. CD8 signaling in microglia/ macrophage M1 polarization in a rat model of cerebral ischemia. PloS One 2018; 13(1): e0186937, https://doi. org/10.1371/journal.pone.0186937.

52. Loane D.J., Kumar A. Microglia in the TBI brain: the good, the bad, and the dysregulated. Exp Neurol 2016; 275(Pt 3): 316-327, https://doi.org/10.1016/j.expneurol.2015.08.018.

53. Truettner J.S., Bramlett H.M., Dietrich W.D. Posttraumatic therapeutic hypothermia alters microglial and macrophage polarization toward a beneficial phenotype. J Cereb Blood Flow Metab 2017; 37(8): 2952-2962, https://doi. org/10.1177/0271678X16680003.

54. Liu L.Q., Liu X.R., Zhao J.Y., Yan F., Wang R.L., Wen S.H., Wang L., Luo Y.M., Ji X.M. Brain-selective mild hypothermia promotes long-term white matter integrity after ischemic stroke in mice. CNS Neurosci Ther 2018; 24(12): 1275-1285, https://doi.org/10.1111/cns.13061.

55. Sweeney M.D., Zhao Z., Montagne A., Nelson A.R., Zlokovic B.V. Blood-brain barrier: from physiology to disease and back. Physiol Rev 2019; 99(1): 21-78, https://doi.org/10.1152/ physrev.00050.2017.

56. Wennberg R.P., Hance A.J. Experimental bilirubin encephalopathy: importance of total bilirubin, protein binding, and blood-brain barrier. Pediatr Res 1986; 20(8): 789-792, https://doi.org/10.1203/00006450-198608000-00018. 
57. Kristensson K. Microbes' roadmap to neurons. Nat Rev Neurosci 2011; 12(6): 345-357, https://doi.org/10.1038/nrn3029.

58. Rifkind J.M., Mohanty J.G., Nagababu E. The pathophysiology of extracellular hemoglobin associated with enhanced oxidative reactions. Front Physiol 2014; 5: 500, https://doi.org/10.3389/fphys.2014.00500.

59. Smith S.L., Hall E.D. Mild pre- and posttraumatic hypothermia attenuates blood-brain barrier damage following controlled cortical impact injury in the rat. Neurotrauma 1996; 13(1): 1-9, https://doi.org/10.1089/neu.1996.13.1.

60. Lotocki G., Vaccari J.P.D., Perez E.R., SanchezMolano J., Furones-Alonso O., Bramlett H.M., Dietrich W.D. Alterations in blood-brain barrier permeability to large and small molecules and leukocyte accumulation after traumatic brain injury: effects of post-traumatic hypothermia. Neurotrauma 2009; 26(7): 1123-1134, https://doi.org/10.1089/neu.2008.0802.

61. Tang X.N., Liu L., Koike M.A., Yenari M.A. Mild hypothermia reduces tissue plasminogen activator-related hemorrhage and blood brain barrier disruption after experimental stroke. Ther Hypothermia Temp Manag 2013; 3(2): 74-83, https://doi.org/10.1089/ther.2013.0010.

62. Liu Y.C., Lee Y.D., Wang H.L., Liao K.H., Chen K.B., Poon K.S., Pan Y.L., Lai T.W. Anesthesia-induced hypothermia attenuates early-phase blood-brain barrier disruption but not infarct volume following cerebral ischemia. PloS One 2017; 12(1): e0170682, https://doi.org/10.1371/journal. pone. 0170682 .

63. Irazuzta J.E., Pretzlaff R., Rowin M., Milam K., Zemlan F.P., Zingarelli B. Hypothermia as an adjunctive treatment for severe bacterial meningitis. Brain Res 2000; 881(1): 88-97, https://doi.org/10.1016/s0006-8993(00)02894-8.

64. Song F., Guo C., Geng Y., Wu X., Fan W. Therapeutic time window and regulation of autophagy by mild hypothermia after intracerebral hemorrhage in rats. Brain Res 2018; 1690: 12-22, https://doi.org/10.1016/j.brainres.2018.04.005.

65. Lee J.E., Yoon Y.J., Moseley M.E., Yenari M.A. Reduction in levels of matrix metalloproteinases and increased expression of tissue inhibitor of metalloproteinase-2 in response to mild hypothermia therapy in experimental stroke. J Neurosurg 2005; 103(2): 289-297, https://doi.org/10.3171/jns.2005.103.2.0289.

66. Li J., Li C., Yuan W., Wu J., Zhao Y. Mild hypothermia alleviates brain oedema and blood-brain barrier disruption by attenuating tight junction and adherens junction breakdown in a swine model of cardiopulmonary resuscitation. PloS One 2017; 12(3): e0174596, https://doi.org/10.1371/journal.pone.0174596.

67. Choi J.S., Park J., Suk K., Moon C., Park Y.K., Han H.S. Mild hypothermia attenuates intercellular adhesion molecule-1 induction via activation of extracellular signal-regulated kinase-1/2 in a focal cerebral ischemia model. Stroke Res Treat 2011; 2011: 846716, https://doi.org/10.4061/2011/846716.

68. Edwards A.D., Yue X., Squier M.V., Thoresen M., Cady E.B., Penrice J., Cooper C.E., Wyatt J.S., Reynolds E.O., Mehmet H. Specific inhibition of apoptosis after cerebral hypoxiaischaemia by moderate post-insult hypothermia. Biochem Biophys Res Commun 1995; 217(3): 1193-1199, https://doi.org/10.1006/bbrc.1995.2895.

69. Eroğlu O., Deniz T., Kisa Ü., Atasoy P., Aydinuraz K. Effect of hypothermia on apoptosis in traumatic brain injury and hemorrhagic shock model. Injury 2017; 48(12): 2675-2682, https://doi.org/10.1016/j.injury.2017.09.032.

70. Liebetrau M., Burggraf D., Martens H.K., Pichler M., Hamann G.F. Delayed moderate hypothermia reduces calpain activity and breakdown of its substrate in experimental focal cerebral ischemia in rats. Neurosci Lett 2004; 357(1): 17-20, https://doi.org/10.1016/j.neulet.2003.12.031.

71. Lu J., Qian H.Y., Liu L.J., Zhou B.C., Xiao Y., Mao J.N., An G.Y., Rui M.Z., Wang T., Zhu C.L. Mild hypothermia alleviates excessive autophagy and mitophagy in a rat model of asphyxial cardiac arrest. Neurol Sci 2014; 35(11): 1691-1699, https://doi. org/10.1007/s10072-014-1813-6.

72. Liu T., Zhao D.X., Cui H., Chen L., Bao Y.H., Wang Y., Jiang J.Y. Therapeutic hypothermia attenuates tissue damage and cytokine expression after traumatic brain injury by inhibiting necroptosis in the rat. Sci $\operatorname{Rep} 2016$; 6: 24547, https://doi. org/10.1038/srep24547.

73. Tomura S., de Rivero Vaccari J.P., Keane R.W., Bramlett H.M., Dietrich W.D. Effects of therapeutic hypothermia on inflammasome signaling after traumatic brain injury. Cereb Blood Flow Metab 2012; 32(10): 1939-1947, https://doi. org/10.1038/jcbfm.2012.99.

74. Zhou M., Wang P., Yang Z., Wu H., Huan Z. Spontaneous hypothermia ameliorated inflammation and neurologic deficit in rat cardiac arrest models following resuscitation. Mol Med Rep 2018; 17(2): 2127-2136, https://doi.org/10.3892/ mmr.2017.8113.

75. Ellis R.J. The molecular chaperone concept. Semin Cell Biol 1990; 1(1): 1-9.

76. Hartl F.U. Molecular chaperones in cellular protein folding. Nature 1996; 381(6583): 571-580, https://doi. org/10.1038/381571a0.

77. Giffard R.G., Xu L., Zhao H., Carrico W., Ouyang Y., Qiao Y., Sapolsky R., Steinberg G., Hu B., Yenari M.A. Chaperones, protein aggregation, and brain protection from hypoxic/ischemic injury. J Exp Biol 2004; 207(Pt 18): 32133220, https://doi.org/10.1242/jeb.01034.

78. Beere H.M. "The stress of dying": the role of heat shock proteins in the regulation of apoptosis. J Cell Sci 2004; 117(Pt 13): 2641-2651, https://doi.org/10.1242/jcs.01284.

79. Muchowski P.J., Wacker J.L. Modulation of neurodegeneration by molecular chaperones. Nat Rev Neurosci 2005; 6(1): 11-22, https://doi.org/10.1038/nrn1587.

80. Voellmy R. On mechanisms that control heat shock transcription factor activity in metazoan cells. Cell Stress Chaperones 2004; 9(2): 122-133, https://doi.org/10.1379/csc14 r.1.

81. Fernandez-Funez P., Rincon-Limas D.E. Launching Hsp70 neuroprotection: two drugs better than one. Cell Cycle 2014; 13(11): 1657-1658, https://doi.org/10.4161/cc.29148.

82. Yenari M.A. Heat shock proteins and neuroprotection. Adv Exp Med Biol 2002; 513: 281-299, https://doi. org/10.1007/978-1-4615-0123-7_10.

83. Calderwood S.K., Mambula S.S., Gray P.J. Jr., Theriault J.R. Extracellular heat shock proteins in cell signaling. FEBS Lett 2007; 581(19): 3689-3694, https://doi.org/10.1016/j. febslet.2007.04.044.

84. Sharma H.S. Hyperthermia induced brain oedema: current status and future perspectives. Indian J Med Res 2006; 123(5): 629-652.

85. Vishwakarma S.K., Paspala S.A.B., Tiwari S.K., Khan A. ATP-binding cassette (ABC) transporters as emerging targets in modulation of neural stem cell behavior in neurodegenerative diseases and cell therapy benefits. JCMR 2014; 6(1): 44-49, https://doi.org/10.22067/jcmr.v6i1. 30375.

86. Mrozek S., Vardon F., Geeraerts T. Brain temperature: physiology and pathophysiology after brain injury. 
Anesthesiol Res Pract 2012; 2012: 989487, https://doi. org/10.1155/2012/989487.

87. Ornitz D.M., Itoh N. The fibroblast growth factor signaling pathway. Wiley Interdiscip Rev Dev Biol 2015; 4(3): 215-266, https://doi.org/10.1002/wdev.176.

88. Thompson L.D., Pantoliano M.W., Springer B.A. Energetic characterization of the basic fibroblast growth factorheparin interaction: identification of the heparin binding domain. Biochemistry 1994; 33(13): 3831-3840, https://doi.org/10.1021/ bi00179a006.

89. Itoh N., Ornitz D.M. Functional evolutionary history of the mouse Fgf gene family. Dev Dyn 2008; 237(1): 18-27, https:// doi.org/10.1002/dvdy.21388.

90. Chen G.Z., Liu Y., Goetz R., Fu L.L., Jayaraman S., Hu M.C., Moe O.W., Liang G., Li X., Mohammadi M. a-Klotho is a nonenzymatic molecular scaffold for FGF23 hormone signalling. Nature 2018; 553(7689): 461-466, https://doi. org/10.1038/nature25451.

91. Lee S., Choi J., Mohanty J., Sousa L.P., Tome F., Pardon E., Steyaert J., Lemmon M.A., Lax I., Schlessinger J. Structures of $\beta$-klotho reveal a 'zip code'-like mechanism for endocrine FGF signalling. Nature 2018; 553(7689): 501-505, https://doi.org/10.1038/nature25010.

92. Kurosu H., Choi M., Ogawa Y., Dickson A.S., Goetz R., Eliseenkova A.V., Mohammadi M., Rosenblatt K.P., Kliewer S.A., Kuro-o M. Tissue-specific expression of $\beta$ Klotho and fibroblast growth factor (FGF) receptor isoforms determines metabolic activity of FGF19 and FGF21. Biol Chem 2007; 282(37): 2668726695, https://doi.org/10.1074/jbc.M704165200.

93. Adams A.C., Cheng C.C., Coskun T., Kharitonenkov A. FGF21 requires $\beta$ klotho to act in vivo. PLoS One 2012; 7(11): e49977, https://doi.org/10.1371/journal.pone.0049977.

94. Tacer K.F., Bookout A.L., Ding X.S., Kurosu H., John G.B., Wang L., Goetz R., Mohammadi M., Kuro-o M., Mangelsdorf D.J., Kliewer S.A. Research resource: comprehensive expression atlas of the fibroblast growth factor system in adult mouse. Mol Endocrinol 2010; 24(10): 20502064, https://doi.org/10.1210/me.2010-0142.

95. Bookout A.L., de Groot M.H.M., Owen B.M., Lee S., Gautron L., Lawrence H.L., Ding X.S., Elmquist J.K., Takahashi J.S., Mangelsdorf D.J., Kliewer S.A. FGF21 regulates metabolism and circadian behavior by acting on the nervous system. Nat Med 2013; 19(9): 1147-1152, https://doi. org/10.1038/nm.3249.

96. Lee P., Brychta R.J., Linderman J., Smith S., Chen K.Y., Celi F.S. Mild cold exposure modulates fibroblast growth factor 21 (FGF21) diurnal rhythm in humans: relationship between FGF21 levels, lipolysis, and cold-induced thermogenesis. J Clin Endocrinol Metab 2013; 98(1): E98-E102, https://doi. org/10.1210/jc.2012-3107.

97. Leng Y., Wang Z., Tsai L.K., Leeds P., Fessler E.B., Wang J., Chuang D.M. FGF-21, a novel metabolic regulator, has a robust neuroprotective role and is markedly elevated in neurons by mood stabilizers. Mol Psychiatr 2015; 20(2): 215223, https://doi.org/10.1038/mp.2013.192.

98. Kuroda M., Muramatsu R., Maedera N., Koyama Y., Hamaguchi M., Fujimura H., Yoshida M., Konishi M., Itoh N., Mochizuki H., Yamashita T. Peripherally derived FGF21 promotes remyelination in the central nervous system. $J$ Clin Invest 2017; 127(9): 3496-3509, https://doi.org/10.1172/ JCI94337.

99. Amiri M., Braidy N., Aminzadeh M. Protective effects of fibroblast growth factor 21 against amyloid-beta ${ }_{1-42}$-induced toxicity in SH-SY5Y cells. Neurotox Res 2018; 34(3): 574-583, https://doi.org/10.1007/s12640-018-9914-2.

100. Chen J., Hu J., Liu H., Xiong Y., Zou Y.C., Huang W.T., Shao M.J., Wu J.M., Yu L., Wang X.J., Wang X., Lin L. FGF21 protects the blood-brain barrier by upregulating PPARY via FGFR1/ $\beta$-klotho after traumatic brain injury. Neurotrauma 2018; 35(17): 2091-2103, https://doi.org/10.1089/neu.2017.5271.

101. Jiang Y., Liu N., Wang Q., Yu Z., Lin L., Yuan J., Guo S., Ahn B.J., Wang X.J., Li X., Lo E.H., Sun X., Wang X. Endocrine regulator rFGF21 (recombinant human fibroblast growth factor 21) improves neurological outcomes following focal ischemic stroke of type 2 diabetes mellitus male mice. Stroke 2018; 49(12): 3039-3049, https://doi.org/10.1161/strokeaha. 118.022119 .

102. Restelli L.M., Oettinghaus B., Halliday M., Agca C., Licci M., Sironi L., Savoia C., Hench J., Tolnay M., Neutzner A., Schmidt A., Eckert A., Mallucci G., Scorrano L., Frank S. Neuronal mitochondrial dysfunction activates the integrated stress response to induce fibroblast growth factor 21. Cell Rep 2018; 24(6): 1407-1414, https://doi.org/10.1016/j.celrep. 2018.07.023.

103. Ruderman N.B., Ross P.S., Berger M., Goodman M.N. Regulation of glucose and ketone-body metabolism in brain of anaesthetized rats. Biochem J 1974; 138(1): 1-10, https://doi. org/10.1042/bj1380001.

104. Kwon M.M., O'Dwyer S.M., Baker R.K., Covey S.D., Kieffer T.J. FGF21-mediated improvements in glucose clearance require uncoupling protein 1. Cell Rep 2015; 13(8): 1521-1527, https://doi.org/10.1016/j.celrep.2015.10.021.

105. Kharitonenkov A., Wroblewski V.J., Koester A., Chen Y.F., Clutinger C.K., Tigno X.T., Hansen B.C., Shanafelt A.B., Etgen G.J. The metabolic state of diabetic monkeys is regulated by fibroblast growth factor-21. Endocrinology 2007; 148(2): 774-781, https://doi.org/10.1210/ en.2006-1168.

106. Bostrom P., Wu J., Jedrychowski M.P., Korde A., Ye L., Lo J.C., Rasbach K.A., Bostrom E.A., Choi J.H., Long J.Z., Kajimura S., Zingaretti M.C., Vind B.F., Tu H., Cinti S., Hojlund K., Gygi S.P., Spiegelman B.M. A PGC1-a-dependent myokine that drives brown-fat-like development of white fat and thermogenesis. Nature 2012; 481(7382): 463-468, https://doi. org/10.1038/nature10777.

107. Lee P., Linderman J.D., Smith S., Brychta R.J., Wang J., Idelson C., Perron R.M., Werner C.D., Phan G.Q., Kammula U.S., Kebebew E., Pacak K., Chen K.Y., Celi F.S. Irisin and FGF21 are coldinduced endocrine activators of brown fat function in humans. Cell Metab 2014; 19(2): 302-309, https:// doi.org/10.1016/j.cmet.2013.12.017.

108. Li D.J., Li Y.H., Yuan H.B., Qu L.F., Wang P. The novel exerciseinduced hormone irisin protects against neuronal injury via activation of the Akt and ERK1/2 signaling pathways and contributes to the neuroprotection of physical exercise in cerebral ischemia. Metabolism 2017; 68: 31-42, https://doi. org/10.1016/j.metabol.2016.12.003.

109. Asadi Y., Gorjipour F., Behrouzifar S., Vakili A. Irisin peptide protects brain against ischemic injury through reducing apoptosis and enhancing BDNF in a rodent model of stroke. Neurochem Res 2018; 43(8): 1549-1560, https://doi. org/10.1007/s11064-018-2569-9.

110. Rao R.R., Long J.Z., White J.P., Svensson K.J., Lou J., Lokurkar I., Jedrychowski M.P., Ruas J.L., Wrann C.D., Lo J.C., Camera D.M., Lachey J., Gygi S., Seehra J., Hawley J.A., Spiegelman B.M. Meteorin-like is a hormone 
that regulates immune-adipose interactions to increase beige fat thermogenesis. Cell 2014; 157(6): 1279-1291, https://doi. org/10.1016/j.cell.2014.03.065.

111. Lan X., Han X., Li Q., Yang Q.W., Wang J. Modulators of microglial activation and polarization after intracerebral haemorrhage. Nat Rev Neurol 2017; 13(7): 420-433, https://doi. org/10.1038/nrneurol.2017.69.

112. Danno S., Itoh K., Matsuda T., Fujita J. Decreased expression of mouse Rbm3, a cold-shock protein, in Sertoli cells of cryptorchid testis. Am J Pathol 2000; 156(5): 16851692, https://doi.org/10.1016/S0002-9440(10)65039-0.

113. Chip S., Zelmer A., Ogunshola O.O., FelderhoffMueser U., Nitsch C., Buhrer C., Wellmann S. The RNAbinding protein RBM3 is involved in hypothermia induced neuroprotection. Neurobiol Dis 2011; 43(2): 388-396, https://doi. org/10.1016/j.nbd.2011.04.010.

114. Kita H., Carmichael J., Swartz J., Muro S., Wyttenbach A., Matsubara K., Rubinsztein D.C., Kato K. Modulation of polyglutamine-induced cell death by genes identified by expression profiling. Hum Mol Genet 2002; 11(19): 2279-2287, https://doi.org/10.1093/hmg/11.19.2279.

115. Yang H.J., Ju F., Guo X.X., Ma S.P., Wang L., Cheng B.F., Zhuang R.J., Zhang B.B., Shi X., Feng Z.W., Wang M. RNA-binding protein RBM3 prevents NO-induced apoptosis in human neuroblastoma cells by modulating p38 signaling and miR-143. Sci Rep 2017; 7: 41738, https://doi. org/10.1038/srep41738.

116. Neumar R.W., DeGracia D.J., Konkoly L.L., Khoury J.I., White B.C., Krause G.S. Calpain mediates eukaryotic initiation factor $4 G$ degradation during global brain ischemia. J Cereb Blood Flow Metab 1998; 18(8): 876-881, https://doi.org/10.1097/00004647-199808000-00007.

117. de la Vega C.M., Burda J., Nemethova M., Quevedo C., Alcázar A., Martín M.E., Danielisova V., Fando J.L., Salinas M. Possible mechanisms involved in the downregulation of translation during transient global ischaemia in the rat brain. Biochem J 2001; 357(Pt 3): 819-826, https://doi. org/10.1042/0264-6021:3570819.

118. Pilotte J., Dupont-Versteegden E.E., Vanderklish P.W. Widespread regulation of miRNA biogenesis at the Dicer step by the cold-inducible RNA-binding protein, RBM3. PloS One 2011; 6(12): e28446, https://doi.org/10.1371/journal.pone.0028446.

119. Peretti D., Bastide A., Radford H., Verity N., Molloy C., Martin M.G., Moreno J.A., Steinert J.R., Smith T., Dinsdale D., Willis A.E., Mallucci G.R. RBM3 mediates structural plasticity and protective effects of cooling in neurodegeneration. Nature 2015 ; $518(7538)$ : 236-239, https://doi.org/10.1038/ nature 14142.

120. Nishiyama $H_{\text {. }}$ Itoh K., Kaneko Y., Kishishita M., Yoshida O.. Fujita J.A glycine-rich RNA-binding protein mediating cold-inducible suppression of mammalian cell growth. J Cell Biol 1997; 137(4): 899-908, https://doi.org/10.1083/ jcb.137.4.899.

121. Li S., Zhang Z., Xue J., Liu A., Zhang H. Cold-inducible RNA binding protein inhibits $\mathrm{H}_{2} \mathrm{O}_{2}$-induced apoptosis in rat cortical neurons. Brain Res 2012; 1441: 47-52, https://doi. org/10.1016/j.brainres.2011.12.053.

122. Zhang M.J., Li W.J., Niu G.M., Leak R.K., Chen J., Zhang F. ATP induces mild hypothermia in rats but has a strikingly detrimental impact on focal cerebral ischemia. Cereb Blood Flow Metab 2013; 33(1): e1-e10, https://doi.org/10.1038/ jcbfm.2012.146.

123. Wang G., Zhang J.N., Guo J.K., Cai Y., Sun H.S., Dong K., Wu C.G. Neuroprotective effects of cold-inducible RNA-binding protein during mild hypothermia on traumatic brain injury. Neural Regen Res 2016; 11(5): 771-778, https://doi. org/10.4103/1673-5374.182704.

124. Liu J., Xue J., Zhang H., Li S., Liu Y., Xu D., Zou M., Zhang Z., Diao J. Cloning, expression, and purification of cold inducible RNA-binding protein and its neuroprotective mechanism of action. Brain Res 2015; 1597: 189-195, https:// doi.org/10.1016/j.brainres.2014.11.061.

125. Zhang H.T., Xue J.H., Zhang Z.W., Kong H.B., Liu A.J., Li S.C., Xu D.G. Cold-inducible RNA-binding protein inhibits neuron apoptosis through the suppression of mitochondrial apoptosis. Brain Res 2015; 1622: 474-483, https://doi. org/10.1016/j.brainres.2015.07.004.

126. Zhang Q., Wang Y.Z., Zhang W., Chen X., Wang J., Chen J., Luo W. Involvement of cold inducible RNA-binding protein in severe hypoxia-induced growth arrest of neural stem cells in vitro. Mol Neurobiol 2017; 54(3): 2143-2153, https://doi. org/10.1007/s12035-016-9761-1.

127. Moreira E.F., Jaworski C.J., Rodriguez I.R. Cloning of a novel member of the reticulon gene family (RTN3): gene structure and chromosomal localization to 11q13. Genomics 1999; 58(1): 73-81, https://doi.org/10.1006/geno.1999.5807.

128. Bastide A., Peretti D., Knight J.R.P., Grosso S., Spriggs R.V., Pichon X., Sbarrato T., Roobol A., Roobol J., Vito D., Bushell M., von der Haar T., Smales C.M., Malluccil G.R., Willis A.E. RTN3 is a novel cold-induced protein and mediates neuroprotective effects of RBM3. Curr Biol 2017; 27(5): 638-650, https://doi.org/10.1016/j.cub.2017.01.047.

129. Masters C.L., Bateman R., Blennow K., Rowe C.C., Sperling R.A., Cummings J.L. Alzheimer's disease. Nat Rev Dis Primers 2015; 1: 15056, https://doi.org/10.1038/nrdp.2015.56.

130. Deng M., He W., Tan Y., Han H., Hu X., Xia K., Zhang Z., Yan R. Increased expression of reticulon 3 in neurons leads to reduced axonal transport of $\beta$ site amyloid precursor proteincleaving enzyme 1. Biol Chem 2013; 288(42): 30236-30245, https://doi.org/10.1074/jbc.M113.480079. 